\title{
Improving Enzyme-Assisted Extraction of Brazilin from Sappanwood (Caesalpinia Sappan L.) Extract by Fungal Cellulase
}

\author{
Dia Septiani, Herman Suryadi*, Abdul Mun'im
}

Dia Septiani, Herman Suryadi*, Abdul Mun'im

\section{Universitas Indonesia, INDONESIA.}

\section{Correspondence}

\section{Herman Suryadi}

Universitas Indonesia, INDONESIA.

E-mail: hsuryadi@farmasi.ui.ac.id

History

- Submission Date: 27-10-2021;

- Review completed: 11-11-2021;

- Accepted Date: 17-11-2021.

DOI : 10.5530/pj.2022.14.4

Article Available online

http://www.phcogj.com/v14/i1

\section{Copyright}

(c) 2022 Phcogj.Com. This is an open access article distributed under the terms of the Creative Commons Attribution 4.0 International license.

\section{ABSTRACT}

Brazilin was one of phytoconstituent from sappanwood that widely used as textile-colouring agent and found in traditional concoction for therapeutic purposes. Due to obtain its maximum level in sappanwood (Caesalpinia sappan L.) extract, the extraction method of brazilin has been developed. Enzyme-assisted extraction (EAE) is one of green chemistry methods to achieve that outcome. This study aims to enhance brazilin level by optimize the EAE condition with fungi cellulase. The cellulase are produced by monoculture Aspergillus niger UICC371 in carboxymethyl cellulose submerged fermentation's media. Sappanwood extracted with fungi cellulase through variation conditions: enzyme concentrations $(2.0 ; 4,0$; $6.0 \%)$; temperature $\left(45,50,55^{\circ} \mathrm{C}\right)$; and time $(1,2,3 \mathrm{hrs})$. The optimization are provided by response surface method-BoxBehnken design and brazilin level was carried out through High Performance Liquid Chromatography (HPLC) with asetonitril : 0,3\% acetic acid in water (14.5: 85.5) as eluents. The study showed that cellulase from monoculture of Aspergillus niger UICC371 showed optimum condition of cellulase-EAE method at $6.0 \%$ concentration enzyme at $50^{\circ} \mathrm{C}$ for 3 hours extraction time which provide an increase in brazilin level to $5.014 \%$ compare to reflux method.

Key Words: Caesalpinia sappan L., Cellulase, Enzyme assisted extraction, Fungi, Response surface method.

\section{INTRODUCTION}

Sappanwood (Caesalpinia sappan L.) plants (Figure 1) belongs to Fabaceae family which the heartwood commonly used as textile and food colouring agents. ${ }^{6}$ Sappanwood contains flavonoid compounds, protosappanin, hematoxylin, and brazilin as main flavonoid. ${ }^{9}$ Sappanwood has been used as therapeutic agent by Chinese traditionalmedicine to reduced inflammation. ${ }^{6}$ and its brazilin known as antioxidant and antibacterial agent and anti-photoaging, hypoglicemic, vasorelaxant, and hepato-protector. ${ }^{4,5}$ Pre-clinical trials on diabetic rats was observed that brazilin from sappanwood reduced blood glucose and improved glucose metabolism in adipose tissue. ${ }^{9}$ It showed that brazilin are potentially used as therapeutic medicine and its level need to be improve based on other extraction process.

The conventional method to extract brazilin from sappanwood had been observed with some eluents (ethanol and methanol). Otherwise, other extraction method, Green-Chemistry method, is more promising recently. That method is widely developed and being an alternative to conventional that used organic eluents. ${ }^{11}$ That method can also improve an active phytoconstituents of natural products-extract than conventional methods. ${ }^{9,14}$ Microwave assisted extraction (MAE), ionic liquid, and its combination methods were two of them that had observed previously. ${ }^{9,14}$ However, that methods yielded lack of brazilin $(0.1-0.9 \%){ }^{9}$ so that need to be improved by other promising method, which used enzyme or by enzyme-assisted extraction (EAE) method.

The enzyme-assisted extraction is an efficient method that approved can increase the yield of phytochemical from plants and fruits, such as naringin (flavonoid) from citrus peels. ${ }^{11}$ and total phenolic from citrus and grape significantly increase up to $25.90-39.72 \% .^{11}$ The use of enzymes (cellulase, pectinase, hemicellulose) assisted the extraction process through degrading the integrity of plant-cell wall. ${ }^{11}$ One of the enzyme, cellulase, known abundant in nature and produced by aerobic fungi Aspergillus niger and Trichoderma reesei. ${ }^{18}$ The high amount of cellulase activity from those fungi can be obtained from carboxymethlcellulose (CMC) as a sole carbon nutrient. ${ }^{15}$ Therefore, cellulase from those fungi can be a promising cellulases which can improve extraction process of sappanwood by producing exo$\beta$-glucanase, endo- $\beta$-glucanase, and $\beta$-glucoside synergistically to breakdown the cellulose structure in plant cell-wall. ${ }^{17}$

Cellulase from Aspergillus niger, Trichoderma reesei, and its mix culture have been produced by submerged-fermentation method through previous research. ${ }^{13}$ That obtained the highest cellulase activity was from A.niger cellulase $(0.467 \mathrm{U} / \mathrm{mL})$. From that result, in this study, cellulase from A.niger is used to extract sappanwood by enzyme-assisted extraction (EAE). Brazilin level from sappanwood extract (cellulase-EAE) is compared with brazilin content from conventional extraction reflux methods because its higher brazilin content produced rather than other conventional extraction process based on our preliminary research study. The HighPerformance Liquid Chromatography (HPLC) method was validated for determining brazilin content in the extract.

\section{MATERIALS AND METHODS}

Dried powder of sappanwood (Caesalpinia sappan L.) was obtained and proven its specimen identity 
by Badan Penelitian Tanaman Rempah dan Obat (BALITTRO), Bogor, West Java. Dried cellulase enzyme from Aspergillus niger UICC 371 from carboxymethyl cellulose submerged fermentation's media (Septiani et al., 2019). All the chemicals were analytical grade, aqua pro injection (IKA Pharmaceutical, Jerman), methanol HPLC grade (Merck, Jerman), acetonitrile HPLC grade (Merck, Jerman), acetic acid glacial (Merck, Jerman), brazilin standard (Sigma Aldrich, USA), 95\% ethanol (Brataco, Indonesia), oven (WTB Binder, Germany), analytical balance (Acculab, USA), hotplate stirrer (Corning, USA), pH meter (Hanna, USA), air shaking incubator (Heidolph, Germany), laminar airflow (Kubota, Japan), ultrasonic bath (Krisbow), digital scales (Vibra HT), hotplate stirrer (IKA C-MAG), high performance liquid chromatography (Shimadzu LC-20AT, Japan), column $\mathrm{C}_{18} 4.6$ $\mathrm{mm} \times 150 \mathrm{~mm}$ (Inertsil), rotary vacuum evaporator (Buchi), centrifuge (Hettich Zentrifugen), micropore 0,45 $\mu \mathrm{m}$ (Whatman), and syringe filter (Agilent).

\section{Experimental design}

Response Surface Method (RSM) was used to design the experiment by software Design Expert 11.0. The experimental were carried out in Box-Behnken (Table 1): 15 runs with three ranged independent variable conditions (enzyme's concentration (2.0-6.0\%), temperature $\left(45-55^{\circ} \mathrm{C}\right)$, time of extraction ( $1-3$ hours) $)$ and 3 centre points. The ranged of independent variables were input based on preliminary test and further specific condition was given by the software. The design was applied to find the optimum levels of the independent variables that result in the maximum content of brazilin. A quadratic equation in experimental optimization that suitable was according to multiple regression procedure and the three dimension (3D) figure surface plot were suggested. ${ }^{2}$

\section{Extraction using fungi cellulase-eae with response surface method ( $\mathrm{rsm}$ ) conditions}

Sappanwood powder (10 g) was extracted using EAE method with aquabidest $(200 \mathrm{~mL}) .{ }^{12}$ The different independent variable conditions given: enzyme's concentration (2.0, 4.0, 6.0\%); temperature (45, $\left.50,55^{\circ} \mathrm{C}\right)$, and time of extraction $(1,2,3$ hours) were according to experimental design. The extract then heated at $90^{\circ} \mathrm{C}$ for $15 \mathrm{mins}$ to inactivate the enzyme and were centrifuged at $8000 \mathrm{~g}, 20^{\circ} \mathrm{C}$ for $15 \mathrm{mins}$ to separate the filtrate. The filtrates were collected and freeze dried to obtain dry mass of the extract (Figure 2). The content of brazilin were measured using HPLC.

Table 1: Determination of experimental design.

\begin{tabular}{|cccc}
\hline Run & $\begin{array}{c}\text { Enzyme } \\
\text { concentration } \\
(\%)\end{array}$ & $\begin{array}{c}\text { Temperature } \\
\left({ }^{\circ} \mathrm{C}\right)\end{array}$ & $\begin{array}{c}\text { Time } \\
\text { (hour) }\end{array}$ \\
\hline 1 & 6 & 50 & 1 \\
2 & 2 & 55 & 2 \\
3 & 2 & 45 & 2 \\
4 & 6 & 50 & 3 \\
5 & 4 & 50 & 2 \\
6 & 4 & 55 & 3 \\
7 & 4 & 45 & 1 \\
8 & 4 & 55 & 1 \\
9 & 6 & 55 & 2 \\
10 & 2 & 50 & 3 \\
11 & 6 & 45 & 2 \\
12 & 4 & 50 & 2 \\
13 & 2 & 50 & 1 \\
14 & 4 & 50 & 2 \\
15 & 4 & 45 & 3 \\
\hline
\end{tabular}

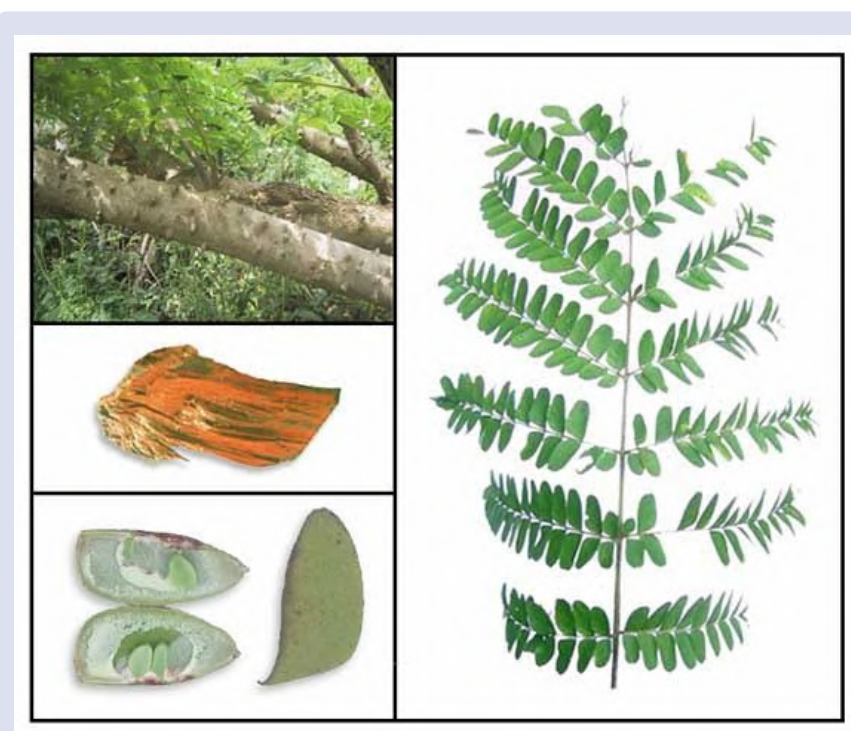

Figure 1: Sappanwood plant's morphology (Source: Protalogue Database 2019).

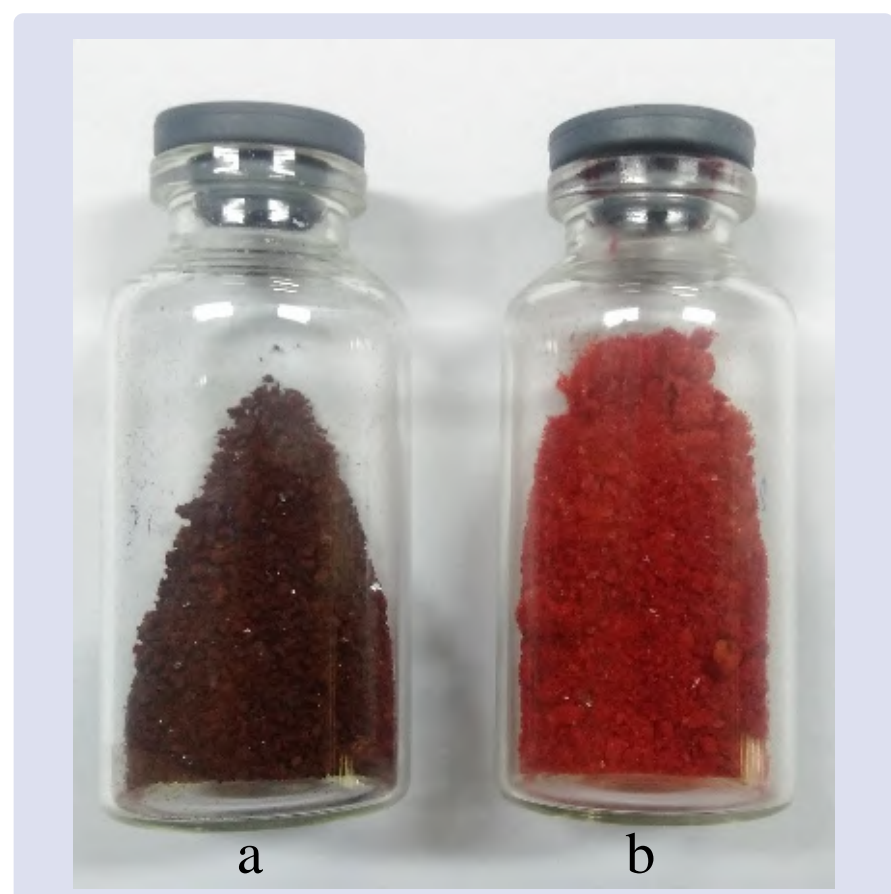

Figure 2: Result of dried extract: reflux method and (b) cellulase-EAE method.

\section{Extraction by reflux with $95 \%$ ethanol}

Sappanwood powder ( $25 \mathrm{~g}$ ) were extracted with $95 \%$ ethanol. ${ }^{9}$ Three cycle of extraction with $500 \mathrm{~mL}$ of $95 \%$ ethanol was obtain under reflux method. The extraction filtrates were collected and evaporated using rotary vacuum evaporator. The dry mass of extract collected (Figure 2) and further used to determine the brazilin content using HPLC.

\section{Determination of brazilin content using HPLC}

The chromatographic system used was HPLC Shimadzu LC-20AT with $0.3 \%$ acetic acid-acetonitrile (85.5:14.5) as the mobile phase. ${ }^{14}$ The detector used was UV-Vis at wavelength of $280 \mathrm{~nm}$ with an Inertsil $\mathrm{C}_{18}$ column $(4.6 \times 150 \mathrm{~mm})$, flow rate $1 \mathrm{~mL} /$ minute and injection volume was $20 \mu \mathrm{L}$. 


\section{HPLC method validation}

The validation tests of HPLC were assessed within three test which are acceptable in suitability test: linearity, accuracy, and precision..$^{1,7}$

\section{System Suitability Test}

Standard solution of brazilin was assessed by six replicates injection and measured the percentage of relative standard deviation (\%RSD) for retention time, peak area, and tailing factor. ${ }^{7}$

\section{Linearity}

The linearity determined by the correlation coefficient $(r)$ value from the equation showed on the calibration curve. ${ }^{1,7}$ The calibration curve made by plotting the area of the chromatogram on the $y$-axis and standard concentration on the $\mathrm{x}$-axis. Brazilin standard solution were made with six concentrations (2.25 ppm; 4.5 ppm; 9 ppm; 18 ppm; 72 ppm; $100 \mathrm{ppm}$ and $280 \mathrm{ppm}$ ).

\section{Accuracy}

The standard solution was added to the sample (spike). Spike samples concentration was compared with sample without spikes. The three spike samples and three samples without spikes were injected and analyzed by HPLC. ${ }^{1}$

\section{Precision}

The three samples were determined inter-day and intra-day. Intraday precision test was carried out by analysing brazilin content in the sample for two days and each day analyse by three samples. ${ }^{1}$

\section{Brazilin determination}

\section{Brazilin standard solution preparation}

Brazilin standard solution were injected $(20 \mu \mathrm{L})$ into HPLC system. The area of six different concentration were plotted to determine a calibration curve with linear regression equations. The standard solution freshly made by dissolving $100 \mu \mathrm{g}$ standard into $1 \mathrm{~mL}$ of methanol to obtain $100 \mathrm{ppm}$ stock solution. Then, the stock solution was diluted into several concentrations (2.25 ppm; $4.5 \mathrm{ppm} ; 9$ ppm; 18 ppm; $72 \mathrm{ppm}$ ). The $1000 \mathrm{ppm}$ stock solution made and diluted into 280 ppm.

\section{Sample solution preparation}

A total of $500 \mathrm{ppm}$ extract concentration of sappanwood was made by diluting $1000 \mathrm{ppm}$ sample stock solution in methanol. The $1000 \mathrm{ppm}$ stock solution was obtained by dissolving $0.005 \mathrm{~g}$ EAE dried extract in $5 \mathrm{~mL}$ methanol. The solution was shaken until homogeneous and filtered using a $0.45 \mu \mathrm{m}$ syringe filter. As much as $2.5 \mathrm{~mL}$ of $1000 \mathrm{ppm}$ stock solution was diluted to $2.5 \mathrm{~mL}$ methanol to obtain $500 \mathrm{ppm}$. Conventional reflux extract $1000 \mathrm{ppm}$ made by dissolved $0.005 \mathrm{~g}$ of dried extract in methanol then diluted to $5 \mathrm{~mL}$, then shaken until homogeneous and filtered using a $0.45 \mu \mathrm{m}$ syringe filter. The stock solution was diluted to obtain $500 \mathrm{ppm}$ in methanol. The solution was stored $\left(4^{\circ} \mathrm{C}\right)$ in a tightly closed vial and protected from light.

\section{Scanning electron microscope (SEM)}

Sappanwood powder (before and after extraction) was examined by SEM. The SEM profile was showed about the morphological characteristic of cell wall before and after extraction process with cellulase-EAE and conventional reflux method with 95\% ethanol.

\section{RESULTS}

\section{HPLC Method Validation}

\section{System Suitability Test}

The RSD percentage of all parameter should be less than 15\% (AOAC 2002). The RSD percentage values of retention time, peak area, and tailing factor less than $15 \%$ (Table 2) were indicate low variation of repeated injection. The tailing factor was $<15$ indicate the symmetry of analyte peak. The system suitability parameters were assessed through AOAC guidelines. The results indicate that system in HPLC were suitable to validation and sample analysis.

\section{Linearity}

The linear regression equation for brazilin standard was $y=16273 \mathrm{x}$ 44056 with a correlation coefficient $(r)=0.9993$ (Figure 3 ). The r-value was $\geq 0.9990$, showed $99 \%$ or high degree of correlation and good linearity on the method.

\section{Accuracy and Precision}

The recovery percentage value should be in the range of $85-110 \%$ and the percentage RSD values should be $<15 \% .{ }^{1}$ The accuracy of the HPLC method for Brazilin determination were showed $93.67 \%$ of percentage recovery value (Table 2). The precision of the HPLC method in intraday and inter-day precision had less than 15\% of \%RSD (1.19 and 3.52). It was determined the good accuracy and precision of the method.

\section{Analysis of brazilin in samples}

The analysis of brazilin in samples showed that sappanwood extract with cellulase-EAE have range peaks at different retention times. The chromatogram of brazilin from sample showed a peak at retention time of 8.4 minutes (Figure $4 \mathrm{a}$ ). That retention time equal to the retention time in brazilin standard chromatogram (Figure 4b).

\section{Optimization of extraction conditions}

The optimization of cellulase-EAE was carried out within three independent variables, enzyme's concentration, temperature, and time of extraction. The response data shown variety range of brazilin content from $14.191-479.609 \mathrm{mg} / \mathrm{g}$ (Table 3). The highest brazilin content was $479.609 \mathrm{mg} / \mathrm{g}$ with $6 \%$ enzyme concentration, $50^{\circ} \mathrm{C}$ temperature and 3 hours of extraction time (run 4 ).

Analysis of Variance (ANOVA) test was obtained to determine the interaction between independent variables to reach the maximum brazilin content. The p-value of regression model was 0.635 (Table 4). The result was determined that the experimental model was not desired to use because the $\mathrm{p}$-value more than 0.05 . It was indicated the model was not significant for three independent variables: A (enzyme concentration); B (extraction temperature); and C (extraction time). It might be significant if more centre point of Box-Behnken design were added up to 5 centre point, so the more of sample that will be assessed. Besides, the p-value of lack of fit test (0.3429) was greater than 0.05 indicates the non-significant model which was desired. It determined that the model that had been chosen was correct.

Table 2: Validation parameters of the HPLC method.

\begin{tabular}{cccccccc}
\hline \multirow{2}{*}{ Equation } & \multirow{2}{*}{$\mathrm{R}^{2}$} & \multicolumn{3}{c}{ System Suitability Test (\%RD) } & \multicolumn{3}{c}{ Precision (\%RSD) } \\
\cline { 2 - 6 } & & Area & Retention time & Tailing factor & Intraday & Interday & Recovery (\%) \\
\hline $\mathrm{y}=16273 \mathrm{x}-44056$ & 0.9993 & 2.69 & 1.11 & 1.49 & 1.19 & 3.52 & 93.67 \\
\hline
\end{tabular}


Table 3: Result of brazilin content from sappanwood extract obtained from cellulase-EAE method.

\begin{tabular}{|c|c|c|c|c|}
\hline Run & $\begin{array}{c}\text { Variable } 1 \\
\text { Enzyme concentration } \\
(\%)\end{array}$ & $\begin{array}{c}\text { Variable } 2 \\
\text { Temperature } \\
\left({ }^{\circ} \mathrm{C}\right)\end{array}$ & $\begin{array}{c}\text { Variable } 3 \\
\text { Time } \\
\text { (hour) }\end{array}$ & $\begin{array}{l}\text { Response } \\
\text { Brazilin content }(\mathrm{mg} / \mathrm{g})\end{array}$ \\
\hline 1 & 6 & 50 & 1 & 373.09 \\
\hline 2 & 2 & 55 & 2 & 19.492 \\
\hline 3 & 2 & 45 & 2 & 181.105 \\
\hline 4 & 6 & 50 & 3 & 479.609 \\
\hline 6 & 4 & 55 & 3 & 36.261 \\
\hline 7 & 4 & 45 & 1 & 334.608 \\
\hline 8 & 4 & 55 & 1 & 241.703 \\
\hline 9 & 6 & 55 & 2 & 14.191 \\
\hline 10 & 2 & 50 & 3 & 459.467 \\
\hline 14 & 4 & 50 & 2 & 170.567 \\
\hline 15 & 4 & 45 & 3 & 28.514 \\
\hline
\end{tabular}

Table 4: ANOVA result on brazilin content from cellulase-EAE.

\begin{tabular}{|c|c|c|c|c|c|c|}
\hline Source & Sum of Squares & df & Mean Square & F-value & p-value & \\
\hline Model & $2.091 \mathrm{E}+05$ & 9 & 23235.92 & 0.8032 & 0.6356 & not significant \\
\hline A-Enzyme concentration & 8200.56 & 1 & 8200.56 & 0.2835 & 0.6172 & \\
\hline C- Extraction time & 3018.34 & 1 & 3018.34 & 0.1043 & 0.7598 & \\
\hline $\mathrm{AB}$ & 1702.87 & 1 & 1702.87 & 0.0589 & 0.8179 & \\
\hline $\mathrm{A}^{2}$ & 9779.03 & 1 & 9779.03 & 0.3380 & 0.5862 & \\
\hline $\mathrm{B}^{2}$ & $1.041 \mathrm{E}+05$ & 1 & $1.041 \mathrm{E}+05$ & 3.60 & 0.1163 & \\
\hline$C^{2}$ & 32531.19 & 1 & 32531.19 & 1.12 & 0.3375 & \\
\hline Residual & $1.447 \mathrm{E}+05$ & 5 & $1.447 \mathrm{E}+05$ & & & \\
\hline Std. Dev. & \multicolumn{2}{|l|}{170.09} & \multicolumn{2}{|r|}{$\mathrm{R}^{2}$} & \multicolumn{2}{|r|}{0.5911} \\
\hline Mean & \multicolumn{2}{|l|}{222.64} & \multicolumn{2}{|r|}{$\operatorname{Adj} \mathrm{R}^{2}$} & \multicolumn{2}{|r|}{-0.1449} \\
\hline \multirow[t]{2}{*}{ C.V. \% } & \multirow[t]{2}{*}{76.40} & & \multicolumn{2}{|r|}{ Pred $\mathrm{R}^{2}$} & \multicolumn{2}{|r|}{-4.1694} \\
\hline & & & \multicolumn{2}{|r|}{ Adeq Precision } & \multicolumn{2}{|r|}{3.0373} \\
\hline
\end{tabular}

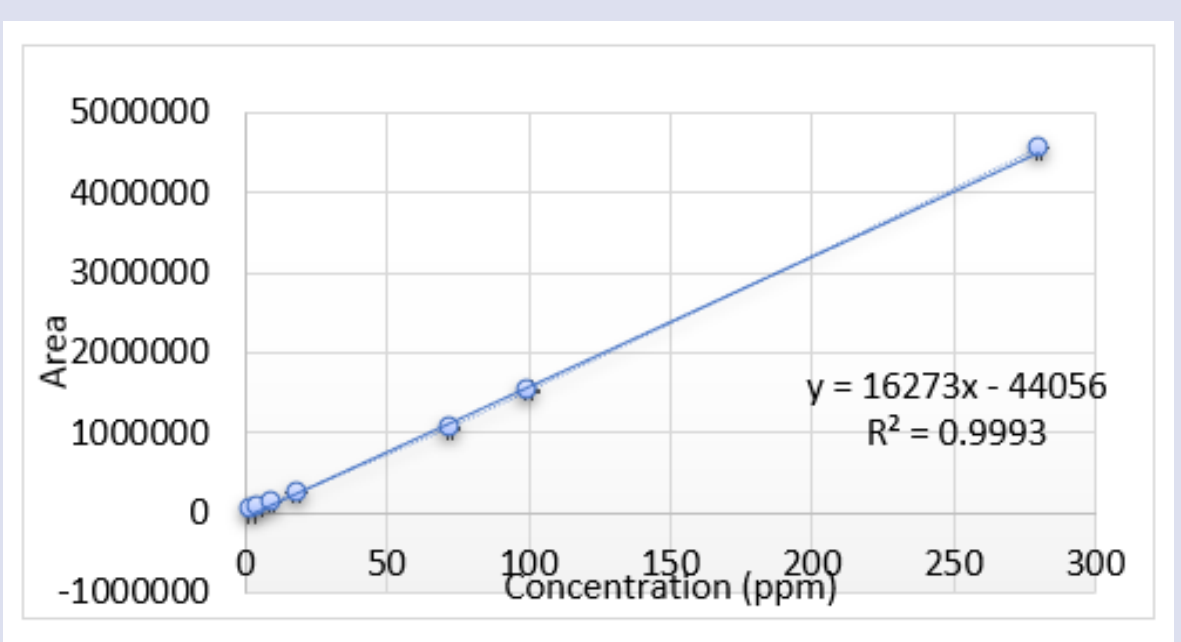

Figure 3: Calibration curve of brazilin standard solutions in six different concentrations. 
Table 5: Comparison of brazilin from extraction.

\begin{tabular}{cccc} 
& Extraction Time & $\begin{array}{c}\text { Solvent amount for } \\
\text { experimental scale }\end{array}$ & $\begin{array}{c}\text { Increase in brazilin content } \\
\text { (\%) }\end{array}$ \\
\hline Reflux & 1hour x 3 cycle & $500 \mathrm{~mL} \mathrm{x} \mathrm{3} \mathrm{cycle}$ & 456.711 \\
Cellulase-EAE & 3 hours & $200 \mathrm{~mL}$ & 479.609
\end{tabular}

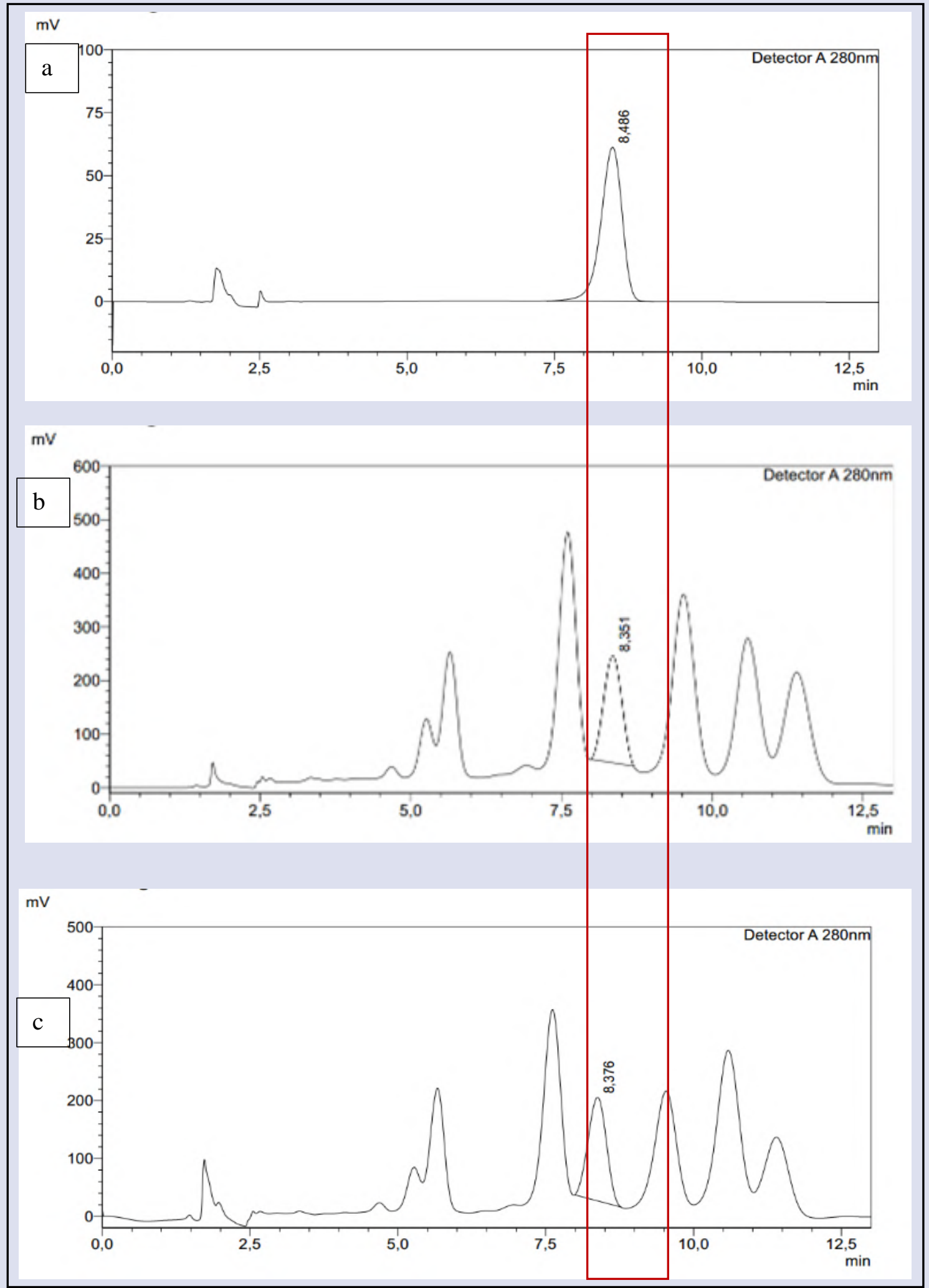

Figure 4: Chromatogram (a) brazilin standard, (b) ethanolic extract of sappanwood, (c) cellulase-EAE extract of sappanwood. 
The coefficient of determination $\left(\mathrm{R}^{2}\right)$ result was 0.5911 which obtain that $59.11 \%$ of independent variables that given in experiments were influence the brazilin content in cellulase-EAE extract. A quadratic regression model optimization that suggested was: $\mathrm{Y}=234.69+32.02 \mathrm{~A}$ $-61.29 \mathrm{~B}-19.42 \mathrm{C}-20.63 \mathrm{AB}-35.91 \mathrm{AC}+25.00 \mathrm{BC}+51.45 \mathrm{~A}^{2}-167.92 \mathrm{~B}^{2}$ $+93.86 \mathrm{C}^{2}$ (A:enzyme concentration; B:extraction temperature; C:extraction time). The software showed the ideal 3D model from RSM that remained an optimum condition to visualize (Figure 5). That 3D surface gave a plot of interaction between three independent variables which the red zone showed an optimum condition for response (brazilin content) (Figure 5).

\section{Comparison of brazilin content between conventional extraction and cellulase-eae extract}

The brazilin content was assessed from conventional and cellulase-EAE method. The conventional extraction was done using reflux method with $95 \%$ ethanol. Brazilin content obtained through reflux was 456.711 $\mathrm{mg} / \mathrm{g}$, and the highest brazilin content from cellulase-EAE method was $479.609 \mathrm{mg} / \mathrm{g}$ (Table 5). In this result, the brazilin content from cellulase-EAE method was $5.014 \%$ higher than the reflux method.

\section{Scanning electron microscope of conventional and cellulase-eae extract}

The examination of sappanwood powder before and after extraction was showed through 500x and 1000x SEM (Figure 6a\&b). The morphology of sappanwood powder after cellulase-EAE process showed more shattered patterns than the conventional extraction process (Figure $6 a \& b)$. Moreover, if it compared to the sappanwood powder simplicia showed the shattered was significantly different (Figure 6a\&c).

\section{DISCUSSIONS}

Sappanwood was extracted using EAE method with fungi cellulase. In this study, dried cellulase of Aspergillus niger that has been produced by submerged fermentation was used to extract brazilin from sappanwood. Cellulase was added to extraction at $0.8 \mathrm{U} / \mathrm{mg}$ (specific activity) and has been diluted with acetic acid buffer $\mathrm{pH} 5.5$ to maintain its enzymatic activity. ${ }^{16}$

The EAE was applied as an extraction method because its simple, effective, and less toxic (because it do not use organic solvent) extracting

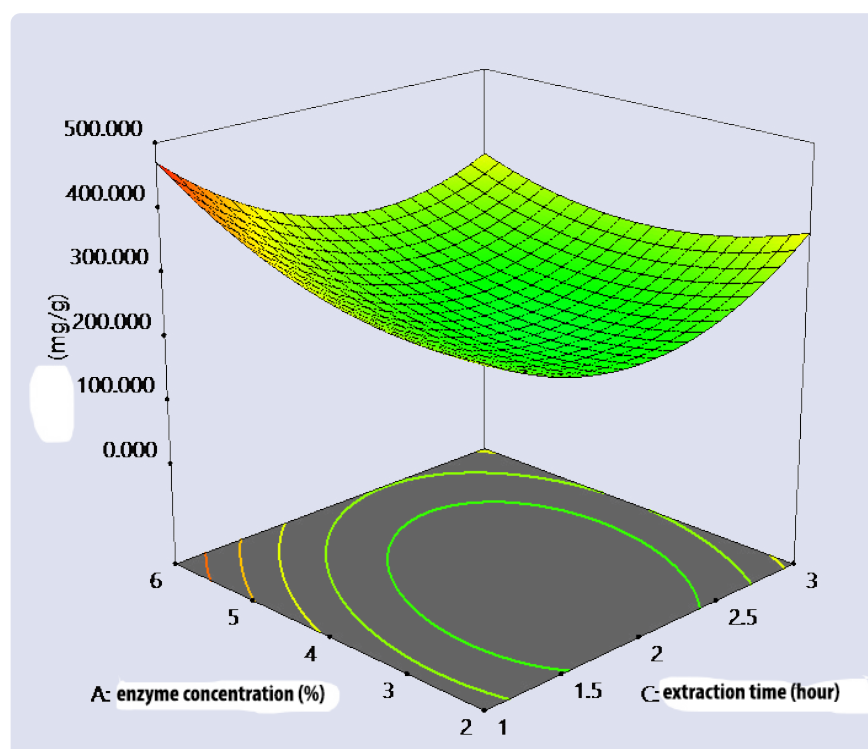

Figure 5: example 3D model of interaction between two independent variables and response.

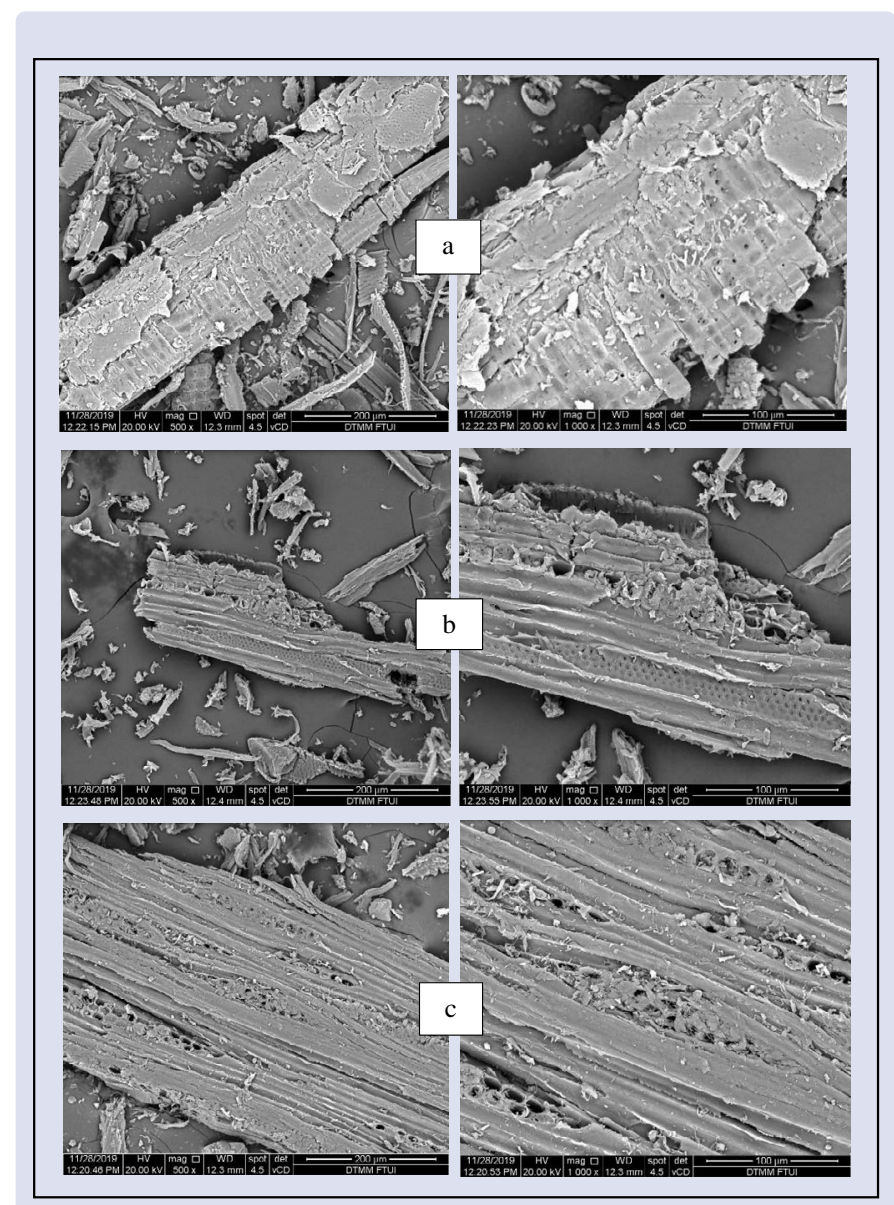

Figure 6: SEM of sappanwood powder in 500x (left) \& 1000x (right) magnificence: after cellulase-EAE; (b) after conventional reflux extraction (ethanolic extract); (c) simplycia.

protocol in natural products. ${ }^{11}$ The applied of cellulase enzyme to extract natural product can destroy the cell wall integrity which the cellulose known arranged $45 \%$ of dried weight in plant. ${ }^{3,10}$ Furthermore, because of the EAE with cellulase in sappanwood have never been reported before, the screening or preliminary tests were conducted before optimization. The preliminary tests with constant independent variable consisting enzyme's concentration, temperature, and time of extraction showed the highest brazilin content with different condition. ${ }^{12}$ In this study, the different condition was made 15 runs experimental according to 3 centre points of Box-Behnken design which made easier and less repetition but still accurate. ${ }^{2}$

\section{CONCLUSIONS}

The cellulase-EAE method for sappanwood was obtained higher brazilin content compared to conventional reflux method. The optimal conditions for extraction using cellulase-EAE was obtained at $6.0 \%$ concentration enzyme at $50^{\circ} \mathrm{C}$ for 3 hours extraction time which provide an increase in brazilin level to $5.014 \%$ compare to reflux method. The SEM morphology characteristic of sappanwood powder were showed that the shattered pattern of cellulase-EAE extract depicted the cellulose wall were destroy by cellulase. It might be a proof of higher brazilin content because of cellulase-EAE method.

\section{ACKNOWLEDGEMENT}

This research was supported by Penelitian Tesis Magister (3055) Grant Research by Ministry of Research, Technology, and Higher Education of the Republic of Indonesia. 


\section{REFERENCES}

1. Association of Agricultural Chemist. AOAC Guidelines for Single Laboratory Validation of Chemical Methods for Dietary Supplements and Botanicals, 2002;1-38.

2. Bakti CP. Optimasi Produksi Enzim Selulase dari Bacillus sp. BPPT CC RK2 dengan Variasi pH dan Suhu menggunakan Response Surface Methodology. Skripsi; 2012.

3. Cheng X, Bi L, Zhao Z, et al. Advances in Enzyme Assisted Extraction of Natural Products. 2015;371-375.

4. Chu MJ, Wang YZ, Itagaki K, et al. Identification of active compounds from Caesalpinia sappan L. extracts suppressing IL-6 production in RAW 264.7 cells by PLS. J of Ethnopharm. 2013;148(1):37-44. (https://doi.org/10.1016/j.jep.2013.03.050)

5. Cuong TD, Hung TM, Kim JC, et al. Phenolic compounds from caesalpinia sappan heartwood and their anti-inflammatory activity. $\mathrm{J}$ of Nat Prod. 2012;75(12):2069-2075. (https://doi.org/10.1021/ np3003673)

6. Dapson R, Bain C. Brazilein : from textile dyeing and folk medicine to biological staining and musical instruments Brazilwood, sappanwood , brazilin and the red dye brazilein: from textile dyeing and folk medicine. 2015 [cited 2021 Jun 12]. Available from: https://doi.org/1 $0.3109 / 10520295.2015 .1021381$

7. FDA. Bioanalytical Method Validation Guidance for Industry Bioanalytical Method Validation Guidance for Industry. U.S. Department of Health and Human Services Food and Drug Administration. Center for Drug Evaluation and Research (CDER), Center for Veterinary Medicine (CVM). 2018

8. Horn S J, Vaaje-kolstad G, Westereng B, et al. Novel enzymes for the degradation of cellulose Novel enzymes for the degradation of cellulose. 2012: https://doi.org/10.1186/1754-6834-5-45

9. Nirmal, Rajput MS, Prasad, et al. Asian Pacific Journal of Tropical Medicine Brazilin from Caesalpinia sappan heartwood and its pharmacological activities: A review. APJTM 2015;8(6):421-430. (https://doi.org/10.1016/j.apjtm.2015.05.014)
10. Peerez J. Biodegradation and biological treatments of cellulose, hemicellulose and lignin: an overview. In. Microb 2002; 5:53-63 (https://doi.org/10.1007/s10123-002-0062-3)

11. Puri M, Sharma D, Barrow C J. Enzyme-assisted extraction of bioactives from plants. Tren in Biotech 2012; 30(1): 37-44. (https:// doi.org/10.1016/j.tibtech.2011.06.014)

12. Rostami H, Mohammad S, Gharibzahedi T. International Journal of Biological Macromolecules Cellulase-assisted extraction of polysaccharides from Malva sylvestris: Process optimization and potential functionalities. Int J of Bio Macro 2017; 101:196-206 (https://doi.org/10.1016/j.ijbiomac.2017.03.078)

13. Septiani D, Suryadi H, Mun'im A, et al. Production of cellulase from Aspergillus niger and Trichoderma reesei mixed culture in carboxymethylcellulose medium as sole carbon. Biodiversitas, 2019;20(12):3539-3544 (https://doi.org/10.13057/biodiv/d201211)

14. Setyaningsih E. Optimization of ionic liquid-based microwave-assisted extraction on brazilin levels from sappan wood and its dipeptidyl peptidase IV inhibition activity. J of Appl Pharm Sc, 2021;11(7):072079.

15. Wahyuningtyas P, Argo BD, Nugroho WA. Studi Pembuatan Enzim Selulase Dari Mikrofungi Trichoderma reesei Dengan Substrat Jerami Padi Sebagai Katalis Hidrolisis Enzimatik Pada Produksi Bioetanol. Bio Kom Trop, 2013;1(1):21-25.

16. Xu B, Hellman U, Ersson B, et al. Purification, characterization and amino-acid sequence analysis of a thermostable, low molecular mass endo- b-1, 4-glucanase from blue mussel, Mytilus edulis. 2000;4977: 4970-4977.

17. Zhang X, Zhang YP. Production and Applications. 2013:131-146.

18. Zhao C, Deng L, Fang H. Mixed culture of recombinant Trichoderma reesei and Aspergillus niger for cellulase production to increase the cellulose degrading capability. Biomass and Bioenerg, 2018;112:9398. (https://doi.org/10.1016/j.biombioe.2018.03.001)

\section{GRAPHICAL ABSTRACT}

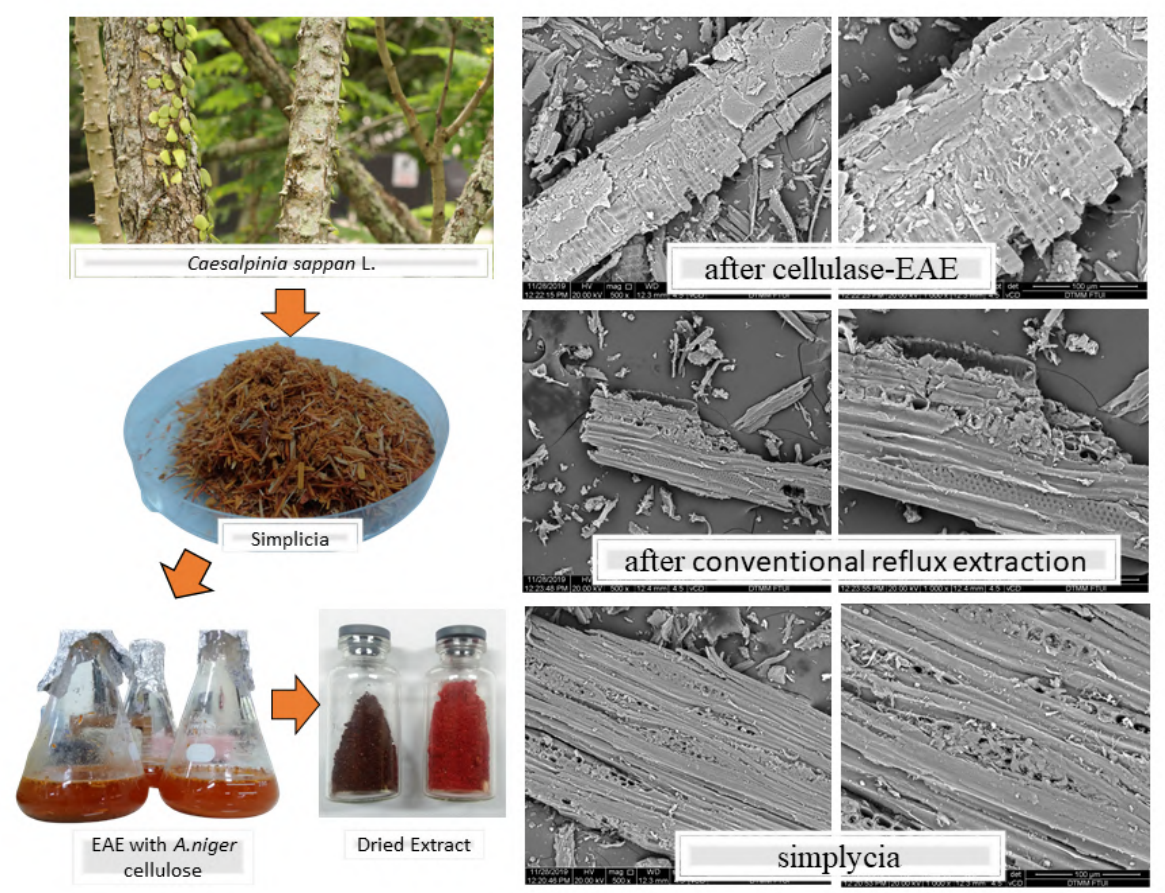

Brazilin was one of phytoconstituent from sappanwood that widely used as textile-colouring agent and found in traditional concoction for therapeutic purposes. Due to obtain its maximum level in sappanwood (Caesalpinia sappan L.) extract, the extraction method of brazilin has been developed. Enzyme-assisted extraction (EAE) is one of green chemistry methods to achieve that outcome. The study showed that cellulase from monoculture of Aspergillus niger UICC371 showed optimum condition of cellulase-EAE method at $6.0 \%$ concentration enzyme at $50^{\circ} \mathrm{C}$ for 3 hours extraction time which provide an increase in brazilin level to $5.014 \%$ compare to reflux method. 


\section{ABOUT AUTHORS}

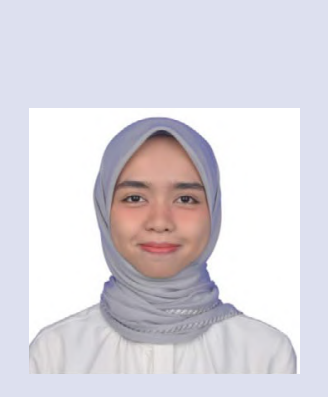

Dia Septiani, S.Si., M.Farm.

Universitas Indonesia, Indonesia 2020

Biology Pharmacy, Microbiology experts

Aphrodisiac Activity of Java Ginseng (Talinum paniculatum Gaertn.) Leaves Ethanolic Extract on Libido Wistar Male Rats (Rattus norvegicus). 2021. Hermina Health Sciences Journal 1(1): 27-33

Production of Cellulase from Aspergillus niger and Trichoderma reesei Mixed Culture in Carboxymethylcellulose Medium as Sole Carbon. 2019. D. Septiani, H. Suryadi, A. Mun'im, W. Mangunwardoyo. Biodiversitas Journal of Biological Diversity 20 (12): 3539-3544

Dr. Herman Suryadi, MS., Apt.

NAIST, Japan 2000

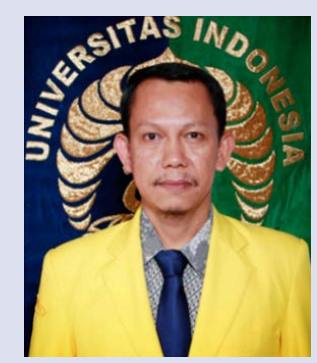

Microbiology and Biotechnology Laboratory

Chemistry Pharmacy, Bioprocess, and Biotechnology experts

Gas Chromatography Analysis of Diallyl Disulphide and Diallyl Trisulphide and Antioxidant Activity in Black Garlic. 2020. H Harmita, H Suryadi, M Syarif, LD Liksas. International Journal of Pharmaceutical Investigation 10 (1), 17-23

Characterization of hydroxypropyl cellulose produce from a-cellulose betung bamboo (Dendrocalamus asper) and it's application in tablet formulation. 2019. H Suryadi, MH Akbar, P Lestari. International Journal of Applied Pharmaceutics, 123-129

Potential of Cellulase of Chaetomium globosum for Preparation and Characterization of Microcrystalline Cellulose from Water Hyacinth (Eichhornia crassipes). 2019. H Suryadi, YPI Lestari, A Yanuar. International Journal of Applied Pharmaceutics 11 (4), 140-146

Prof. Dr. Abdul Mun'im, M.Si., Apt.

Tsukuba University, Japan 2004

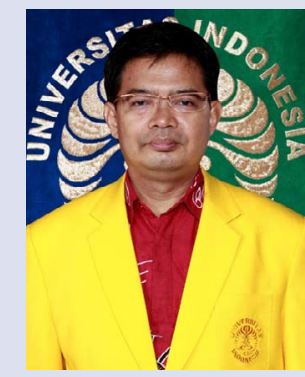

Phytochemistry and Pharmacognocy Laboratory

Phytochemistry and Biosynthesis experts

Formulation and Evaluation of Phytosome Lotion from Nothopanaz scutellarium Leaf Extract for Hair Growth. 2021. I,A. Rahmi, A. Mun'im, M. Jufri. International Journal of Applied Pharmaceutics 13 (6): 178-185

Natural Deep Eutetic Solvents (NADES): Phytochemical Extraction Performance Enhanced Pharmaceutical and Nutraceutical Product Development. 2021. N.Putu, E. Hikmawanti, D. Ramadon., A. Mun'im. Plants 10 (10): 2091

Optimization of betaine-sorbitol natural deep euthetic solvent-based ultrasound-assisted extraction and pancreatic lipase inhibitory activity of chlorogenic acid and caffeine content from robusta green coffee beans. 2021. I, Ahmad, A.M. Syakfanaya, A. Ma'mur, F.C. Saputri. Heliyon 7 (8): e07702

Cite this article: Septiani D, Suryadi H, Mun'im. Improving Enzyme-Assisted Extraction of Brazilin from Sappanwood (Caesalpinia Sappan L.) Extract by Fungal Cellulase. Pharmacogn J. 2022;14(1): 21-28. 